\title{
Location Characteristics of Accommodation Facilities Selected by Tourists in Surakarta City, Central Java Province
}

\author{
Tristano Edwan Cancer Ananta*, M. H. Dewi Susilowati, and Ratri Candra Restuti ${ }^{1}$ \\ Department of Geography, University of Indonesia, Jalan Margonda Raya, Pondok Cina, Beji, \\ Depok City - Indonesia
}

\begin{abstract}
The city of Surakarta is one of the cultural and historical tourist destinations that continues to develop in Indonesia. The trend of an increase in the number of tourists in 2016-2018 has led to the emergence of many accommodation facilities in the city of Surakarta. Differences in location characteristics in each accommodation facility will affect tourists in choosing accommodation facilities. This study aims to determine the characteristics of the location of accommodation facilities chosen by domestic and foreign tourists in the city of Surakarta, as well as the relationship between the characteristics of the location of accommodation facilities with the characteristics of tourists based on the age and place of origin of tourists. This study uses a spatial comparison analysis method and uses a chi-square statistical analysis to see the relationship between variables, such as the characteristics of the location of accommodation facilities and characteristics of tourists. The results of this study indicate that the location characteristics of the accommodation facilities chosen by foreign and domestic tourists are different. Foreign tourists tend to choose star hotels, while for domestic tourists the choice varies, namely star hotels and non-star hotels. In addition, there is a relationship between the characteristics of domestic tourists with the characteristics of the location of selected accommodation facilities, while for the characteristics of foreign tourists there is no relationship with the characteristics of the location of selected accommodation facilities.
\end{abstract}

Keywords: Accommodation Facilities, Location Characteristics, Tourist Characteristics

\section{Introduction}

Surakarta City or also known as Solo City is one of the cultural and historical tourist destinations in Indonesia. The city of Surakarta continues to increase its potential as a tourist city by carrying the slogan "Solo the Spirit of Java" as a form of imaging that the city of Surakarta is a center for cultural and historical tourism in Indonesia, especially in

\footnotetext{
*Corresponding author : tristano.edwan@ui.ac.id
} 
Java [1]. The city of Surakarta has locations that represent that image in the form of historic buildings and museums that store various items from the past. These locations are the ones that finally become tourist attractions in the city of Surakarta.

The existence of various cultural and historical tourism objects in the city of Surakarta makes this city one of the favorite cities to be chosen as a place to tour in Indonesia. People who come to carry out these tourism activities are referred to as tourists. Tourists based on their place of origin can be divided into domestic and foreign tourists [2]. In 2016 the number of tourist arrivals in the city of Surakarta was 4,395,550 tourists, divided by $4,361,868$ domestic tourists and 33,682 foreign tourists. Then in 2018 the number of tourists increased to $4,695,820$ tourists consisting of 4,657,283 domestic tourists and 38,537 foreign tourists [3]. The trend of increasing the number of tourists who come to the city of Surakarta every year is a potential that can benefit the management of secondary facilities that are in the vicinity of tourist attractions. In the development of tourism, the availability of secondary tourism facilities is one important aspect [4]. These secondary facilities include (1) accommodation facilities; (2) culinary facilities; and (3) shopping facilities [5]. Therefore, it can be said that one of the things that can support the development of tourism in an area is the availability of accommodation facilities.

Accommodation is a business providing services that use a building or part of a building to be provided specifically for a place to stay and obtain other facilities with payment on a daily basis [6]. Accommodation facilities can also be interpreted as a business service sector that provides room facilities to stay overnight and provides various types of service facilities, such as food and beverage supply facilities, convention and exhibition facilities, as well as recreational and entertainment facilities [7]. In 2019 accommodation facilities in Surakarta City were recorded as many as 165 accommodation facilities [8]. Of the 165 existing accommodation facilities, 52 are star-rated and 113 are non-star hotels. Starred hotels include 1 - 5 star hotels, while non-star hotels include jasmine hotels (hotel melati in bahasa), home stay and guest house [8].

The more developing tourism in the city of Surakarta, the more hospitality buildings or accommodation facilities in the area. This is due to the fact that accommodation facilities are always needed by tourists who come to a particular city to stay overnight in various tourist needs. In the process of selecting accommodation facilities, tourists will be influenced by two factors, the first is an internal factor that originates from within tourists such as the place of origin and age; then the second factor is an external factor in the form of the location characteristics of the accommodation facilities to be chosen [9].

Location characteristics can be reviewed through site and situation aspects. Site is an internal characteristic of a location which is a physical characteristic of that location, whereas situation is an external characteristic that is around that location [10]. Each accommodation facility has location characteristics that may differ from one another. The difference in location characteristics in each accommodation facility is one of the things that will influence tourists in choosing accommodation facilities. Therefore this study aims to determine the characteristics of the location of accommodation facilities chosen by domestic and foreign tourists in the city of Surakarta and the relationship between the characteristics of the location of accommodation facilities with the characteristics of tourists based on the age and place of origin of tourists. 


\section{Methodology}

\subsection{Research Areas}

Surakarta City is one of the major cities in Central Java Province. Astronomically the location of Surakarta City is located between $7^{\circ} 36^{\prime}-7^{\circ} 56^{\prime}$ South Latitude (S) and $110^{\circ}$ 45 '15 "- $110^{\circ} 45^{\prime} 35^{\prime \prime}$ East Longitude (E). Surakarta City has a northern boundary with Boyolali Regency and Karanganyar Regency, East with Karanganyar Regency and Sukoharjo Regency, South with Sukoharjo Regency, and West with Sukoharjo Regency and Karanganyar Regency (figure 1).

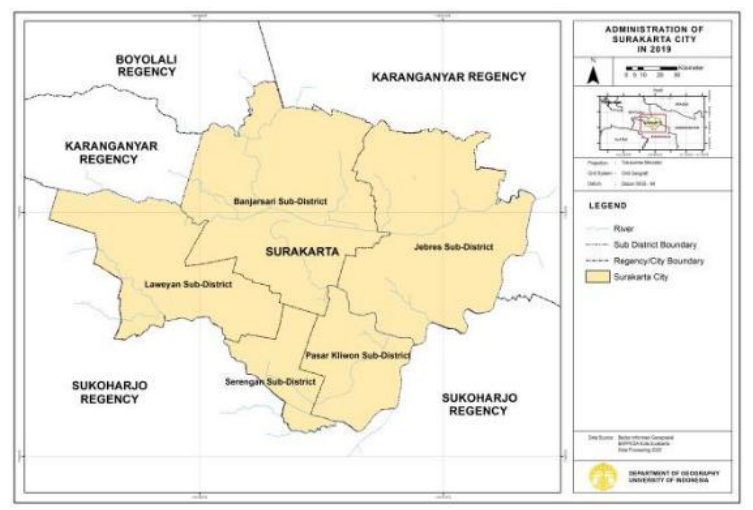

Fig. 1. Map of Surakarta City Administration

\subsection{Data Collection}

The data needed in this study along with its data sources can be seen in table 1 . This study uses a questionnaire as a tool to get information on tourist characteristics, namely the age and place of origin of tourists. The questionnaire in this study was distributed online using an online form (google form). 
Table 1. Research Data

\begin{tabular}{|c|c|c|c|}
\hline No & Data & Data Type & Data Source \\
\hline 1 & Surakarta City Area Boundaries & \multirow{5}{*}{$\begin{array}{l}\text { Secondary } \\
\text { Data }\end{array}$} & BAPPEDA Kota Surakarta \\
\hline 2 & Surakarta City Land Use & & BAPPEDA Kota Surakarta \\
\hline 3 & Surakarta City Road Network & & BAPPEDA Kota Surakarta \\
\hline 4 & Surakarta City Public Transport Line & & $\begin{array}{l}\text { Dinas Perhubungan Kota } \\
\text { Surakarta }\end{array}$ \\
\hline 6 & $\begin{array}{c}\text { Location of Accommodation Facilities in } \\
\text { Surakarta City }\end{array}$ & & BPS Kota Surakarta \\
\hline 7 & Age of Tourist & \multirow{2}{*}{ Primary Data } & Online Questionnaire \\
\hline 8 & Place of Origin of Tourist & & Online Questionnaire \\
\hline
\end{tabular}

\subsection{Data Processing}

In this study the data that has been obtained will be processed in several steps, including:

1) Combine the location data of tourist choice accommodation facilities with the Surakarta City administration map to produce a map of the distribution of tourist choice accommodation facilities in the City of Surakarta;

2) Process indicator data in site variables, namely types of accommodation facilities;

3) Classify situation variables consisting of land use around accommodation facilities and their accessibility;

4) Create a type of location facility location characteristics based on the type of site and situation variable;

5) Process tabulation data on the characteristics of foreign and domestic tourists obtained from the results of the questionnaire;

6) Managing data from observations using Microsoft Excel software and then tabulating variable characteristics of the location of accommodation facilities and tourist characteristics;

7) Data will be processed spatially using GIS (Geographic Information Systems) and maps as its output;

8) Analyzing the relationship between the characteristics of the location of accommodation facilities with the characteristics of tourists (domestic and foreign) using SPSS software.

\subsection{Data Analysis}

The analytical method used in this study is the spatial comparation analysis method to compare the characteristics of domestic and foreign tourists with the location characteristics 
of each accommodation facility that has been selected. The next analysis used is the chisquare analysis method to determine the relationship between characteristics of the location of accommodation facilities with the characteristics of tourists (domestic and foreign) [11]. In the chi-square analysis method, if the calculated chi-square value $\geq$ chi-square table then it shows that there is a relationship between the characteristics of the location of accommodation facilities with the characteristics of tourists (domestic and foreign), whereas if the calculated chi-square value $<$ chi-square table shows that there is no relationship between the characteristics of the location of accommodation facilities with the characteristics of tourists (domestic and foreign).

\section{Results and Discussion}

\subsection{Location Characteristics of Accommodation Facilities}

\subsubsection{Site}

Based on the results of the classification of types of accommodation facilities, researchers grouped site characteristics into 2 classes. The grouping of types of accommodation facilities is based on similarities and differences in the characteristics of each accommodation facility. The grouping of types of accommodation facilities is as follows:

- Star Hotel

- Non-Star Hotel

Star hotels in this study consist of hotels that have characteristics of 1 to 5 stars with a total of 53 accommodation facilities. While for non-star hotels there are 31 accommodation facilities consisting of jasmine hotels, home stays and guest houses.

\subsubsection{Situation}

Based on the results of the classification of indicators in the situation variable, namely aspects of accessibility and land use aspects, a type of tourist choice accommodation facility situation exists in Surakarta City, including:

- Strategic

- Strategic enough

"Strategic enough" accommodation facilities are accommodation facilities that have easy enough accessibility and sufficient land use variation, easy enough accessibility and very variable land use, and easy accessibility and sufficient land use variation. Whereas accommodation facilities with a "strategic" type of situation are accommodation facilities that have easy accessibility and very varied land use, very easy accessibility and sufficient land use variations, and very easy accessibility and and very varied land use. Of the total accommodation facilities chosen by tourists in the city of Surakarta, the most numerous were "quite strategic" type of accommodation facilities, totaling 44 accommodation facilities. Whereas accommodation facilities with type of "strategic" situation totaled 40 accommodation facilities. 
Based on the results of the type of site and the situation of the tourist choice accommodation facilities that have been found, the characteristics of the location of the tourist choice accommodation facilities have been formed. This location characteristic is formed from the combination of site type and situation type from each tourist choice accommodation facility. There are 4 (four) characteristics of the location of the tourist choice accommodation facilities that have been formed, namely:

- Star Hotel \& Strategic

- Star Hotel \& Strategic enough

- Non-Star Hotel \& Strategic

- Non-Star Hotel \& Strategic enough

The characteristic location for the accommodation facilities chosen by most tourists is the "Star Hotel \& Strategic" which is a total of 32 accommodation facilities. The characteristic location of accommodation facilities "Star Hotel \& Strategic enough" has a total of 21 accommodation facilities. Then the characteristics of the location of accommodation facilities "Non-Star Hotel \& Strategic" amounted to at least as many as 8 accommodation facilities. Furthermore, for the characteristics of the location of accommodation facilities "Non-Star Hotel \& Strategic enough" has a total of 23 accommodation facilities. The distribution of locations of accommodation facilities based on location characteristics can be seen in Figure 2.

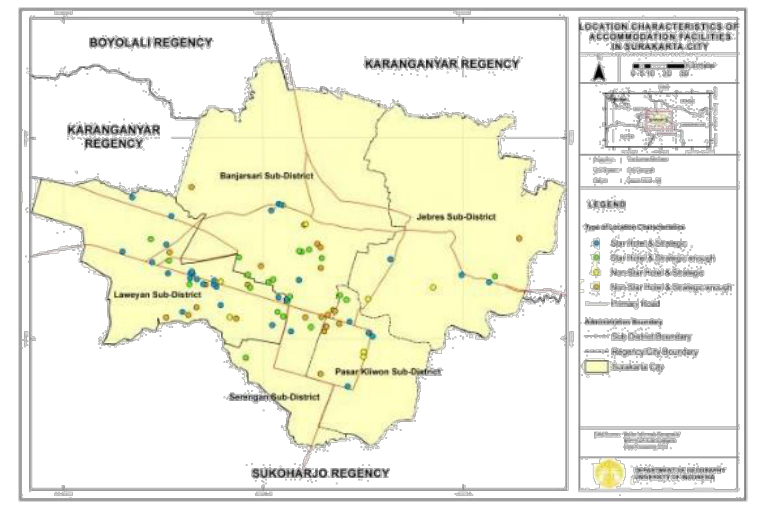

Fig. 2. Map of Location Characteristics of Accommodation Facilities by Tourist Choices

\subsection{Tourist Characteristics}

\subsubsection{Characteristics of Foreign Tourists}

Based on the results of primary data collection using a questionnaire distributed online obtained as many as 27 foreign tourist respondents. In this study the characteristics of tourists are divided into 2, namely age and place of origin. First, based on the age range classification, it can be seen that the characteristics of foreign tourists show 2 age classifications, namely the teenager age (10 tourists) and the adult age (17 tourists). Then the second, based on the place of origin, obtained a number of 13 nationalities. Malaysian citizenship is the most, with 5 tourists. Next the researchers regrouped the places of origin of foreign tourists into 2 groups of places of origin of foreign tourists, namely:

- From Asia Continents

- From Outside Asia Continents 
Furthermore, researchers classify or combine characteristics of foreign tourists based on age classification and place of origin classification to produce characteristics of foreign tourists. There are 4 characteristics of foreign tourists that have been formed, namely, as follows:

- Tourists from Asia \& Teenager

- Tourists from Asia \& Adult

- Tourists from Outside Asia \& Teenager

- $\quad$ Tourists from Outside Asia \& Adult

The characteristics of foreign tourists who have the most number of tourists are "tourists from Asia \& adult" amounting to 9 tourists. For the characteristics of foreign tourists with the characteristics of "tourists from outside Asia \& adults" amounted to 8 tourists. Then for the characteristics of foreign tourists with the characteristics of "tourists from Asia \& teenager" and "tourists from outside Asia \& teenager" each has a total of 5 tourists (figure 3a).

\subsubsection{Characteristics of Domestic Tourists}

Domestic tourists who travel and stay at accommodation facilities in the city of Surakarta in this study based on data collection totaling 283 tourists. The characteristics of domestic tourists are divided into 2, namely age and place of origin. First, based on the age range classification, it can be seen that the characteristics of domestic tourists show 2 age classifications, namely the teenager age consist of 210 tourists and the adult age consist of 73 tourists. Then the second, based on the place of origin, there are areas of origin of domestic tourists as many as 26 provinces in Indonesia. Central Java Province is the most origin area with 85 tourists. Then the researchers regrouped the area of origin of domestic tourists into 2 groups, namely:

- $\quad$ From Java

- From Outside Java

After obtaining the characteristics of domestic tourists based on age classification and place of origin classification, the researchers then group or combine the characteristics of domestic tourists based on age classification and classification of the place of origin to produce characteristics of domestic tourists. There are 4 characteristics of domestic tourists that have been formed, as follows:

- $\quad$ Tourists from Java \& Teenager

- $\quad$ Tourists from Java \& Adult

- Tourists from Outside Java \& Teenager

- $\quad$ Tourists from Outside Java \& Adult

The characteristics of domestic tourists who have the most number of tourists are "tourist from Java \& teenager" amounting to 181 tourists. Whereas the characteristics of domestic tourists with the fewest number of tourists are the characteristics of "tourist from outside Java \& adults" totaling 15 tourists (figure $3 b$ ). 


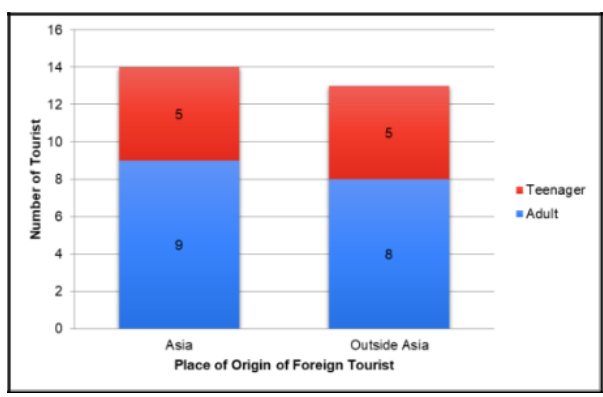

(a)

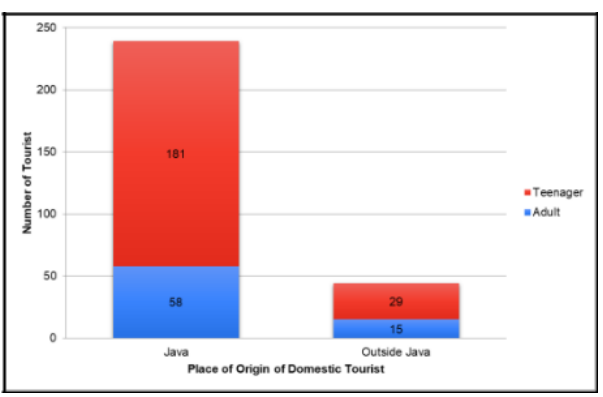

(b)

Fig. 3. (a) Total Characteristics of Foreign Tourists (b) Total Characteristics of Domestic Tourists

\subsection{Relationship between Location Characteristics of Accommodation Facilities and Tourist Characteristics}

\subsubsection{Relationship between Location Characteristics of Accommodation Facilities and Foreign Tourist Characteristics}

Foreign tourists tend to choose to stay in accommodation facilities that have the characteristics of the location of a star hotel as a place to stay while in the city of Surakarta, only the strategic / strategic enough aspects that distinguish in the election. Foreign tourists who choose to stay in accommodation facilities with "star hotel \& strategic" location characteristics are 17 tourists while foreign tourists who choose to stay in accommodation facilities with "star hotel \& strategic enough" location characteristics consist 10 tourists. Therefore it can be said that foreign tourists tend to prefer accommodation facilities that have the characteristics of "star hotel \& strategic" on the west side of the city of Surakarta because of the availability of adequate facilities and strategic location of accommodation facilities that are on the main road (arterial / collector road ) (figure 4).

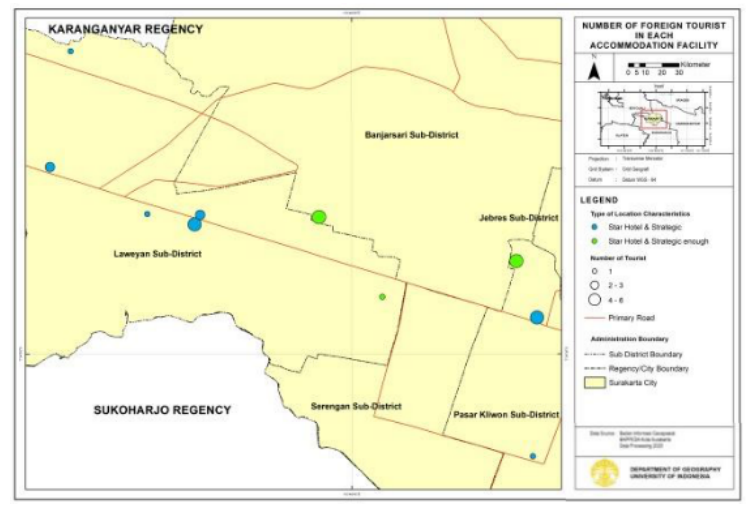

Fig. 4. Map of Number of Foreign Tourists in Each Accommodation Facility

From the results of the chi-square test on SPSS (table 2), the calculated chi-square value was 2.462 with a significance level $(\alpha)=5 \%$ and degrees of freedom $(\mathrm{df})=3$. Based on the chi-square table, the value of chi-square table is 7,815 . Because the calculated chi-square value $<$ chi-square table $(2,462<7,815)$, it can be concluded that there is no relationship 
between the characteristics of foreign tourists with the characteristics of the location of selected accommodation facilities in the city of Surakarta.

Table 2. Chi-Square Test Results

\begin{tabular}{|l|r|r|r|}
\hline & Value & df & Asymp.sig (2-sided) \\
\hline Pearson Chi-Square & $2.462^{\mathrm{a}}$ & 3 & .482 \\
\hline Likelihood Ratio & 2.497 & 3 & .476 \\
\hline N of Valid Cases & 27 & & \\
\hline
\end{tabular}

\subsubsection{Relationship between Location Characteristics of Accommodation Facilities and Domestic Tourist Characteristics}

Domestic tourists tend to prefer staying in accommodation facilities that have the location characteristics of a "star hotel \& strategic" as many as 160 domestic tourists choose it. While domestic tourists who choose the characteristics of the location of "non-star hotel \& strategic" which amounted to 15 tourists. Therefore it can be said that for the characteristics of domestic tourists tend to mostly choose the characteristics of "star hotel \& strategic" acommodation facilities on the west side of Surakarta City along one of the main streets of Surakarta City (Jalan Brigjen Slamet Riyadi) to the center of Surakarta City (near the Keraton Surakarta and Surakarta Square (figure 5) due to the availability of adequate facilities, location close to the main road (strategic location), close to tourist attractions, as well as the results of travel application recommendations such as Traveloka, Agoda, etc.

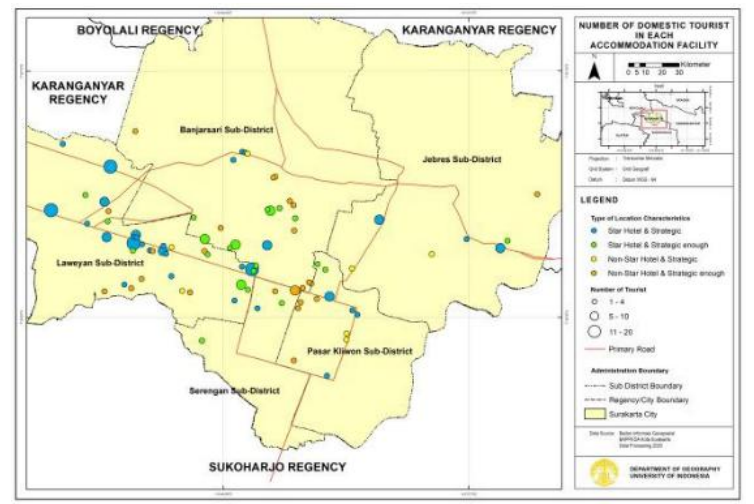

Fig. 5. Map of Number of Domestic Travelers in Each Accommodation Facility

From the results of the chi-square test on SPSS (table 3), the calculated chi-square value was 19,005 with a significance level $(\alpha)=5 \%$ and degrees of freedom $(\mathrm{df})=9$. Based on the chi-square table, the value of chi-square table is 16,919 . Because the calculated chisquare value $\geq$ chi-square tables $(19,005>16,919)$, then it can be concluded that there is a relationship between the characteristics of domestic tourists with the characteristics of the location of the selected accommodation facilities in the city of Surakarta. This is because domestic tourists tend to pay more attention to location characteristics in choosing accommodation facilities. Most domestic tourists prefer to stay in accommodation facilities 
that have "star \& strategic hotel" location characteristics compared to other accommodation facility location characteristics.

Table 3. Chi-Square Test Results

\begin{tabular}{|l|r|r|r|}
\hline & Value & df & Asymp.sig (2-sided) \\
\hline Pearson Chi-Square & $19.005^{\mathrm{a}}$ & 9 & .025 \\
\hline Likelihood Ratio & 21.746 & 9 & .010 \\
\hline N of Valid Cases & 283 & & \\
\hline
\end{tabular}

\section{Conclusions}

The location characteristics of the accommodation facilities chosen by foreign and domestic tourists are different. All of foreign tourists tend to choose star hotels, while for domestic tourists more varied in the selection such as star hotels and non-star hotels (jasmine hotels, home stays, and guest houses). Furthermore, foreign tourists prefer accommodation facilities with the characteristics of a "star hotel \& strategic" on the west side of the city of Surakarta because of the availability of adequate facilities and the location of strategic accommodation facilities which are on the main road (arterial / collector road). Whereas domestic tourists mostly choose accommodation facilities with the characteristics of a "star hotel \& strategic" on the west side of Surakarta City along one of the main streets of Surakarta City (Jalan Brigjen Slamet Riyadi) to the center of Surakarta City (near the Surakarta Palace and Surakarta Square). From the results of statistical tests show that there is no relationship formed between the characteristics of foreign tourists with the characteristics of the location of selected accommodation facilities. Meanwhile it was also found that there was a relationship formed between the characteristics of domestic tourists with the characteristics of the location of the chosen accommodation facilities, because domestic tourists paid more attention to the characteristics of the location in choosing accommodation facilities. 


\section{References}

1. Sarim, W. Tri, Pengaruh Fasilitas Wisatawan Terhadap Motivasi Kunjungan Wisatawan, Jurnal Hospitality dan Pariwisata Vol.3 (No.2) : 294-374. (2017).

2. Smith, Stephen L.S, Tourism Analysis: A Handbook, England: Longman Group, (1998).

3. BPS Kota Surakarta, Kota Surakarta Dalam Angka 2018, Kota Surakarta: BPS, (2018).

4. Wenny, F, Pola Ruang Kegiatan Ekonomi Masyarakat di Kawasan Wisata Cipanas, Kabupaten Garut, Skripsi, Depok: Universitas Indonesia, (2010).

5. Yoeti, O.A, Pengantar Ilmu Pariwisata, Bandung: Angkasa, (1996).

6. BPS Kota Surakarta, Profil Hotel di Kota Surakarta, Kota Surakarta: BPS, (2016).

7. Suryo, A, Tata Cara Mengurus Izin Usaha, Yogyakarta: Pustaka Yustisia, (2008).

8. BPS Kota Surakarta, Direktori Hotel dan Akomodasi Lainnya di Kota Surakarta Tahun 2019, Kota Surakarta: BPS, (2019).

9. Burton, R., Travel Geography, Second Edition, Singapore: Pitman Publishing, (1995).

10. Summatmadja, Nursid, Studi Geografi: Suatu Pendekatan dan Analisa Keruangan, Bandung: Alumni, (1988).

11. Usman, H, Purnomo S.A, Pengantar Statistika, Jakarta: Bumi Aksara, (2000). 